\title{
Ambushes related to collecting patients' consent for medical procedures by family doctors
}

\author{
JAROSŁAW DROBNIK ${ }^{1, A, B, D}$, JAKUB TRNKA ${ }^{2, A, ~ D, ~ R O B E R T ~ S U S Ł O ~}{ }^{1, A, ~ B, ~ D-F ~}$ \\ ${ }^{1}$ Department of Gerontology, Department of Public Health, Faculty of Health Sciences, Wroclaw Medical University, \\ Poland \\ ${ }^{2}$ Department of Forensic Medicine, Faculty of Medicine, Wroclaw Medical University, Poland
}

A - Study Design, B - Data Collection, C - Statistical Analysis, D - Data Interpretation, E - Manuscript Preparation, F - Literature Search, G - Funds Collection

Summary A patient's right to express consent - or lack thereof - to receive medical service is rooted primarily in the Polish Parliament's Act on Patient's Rights and Patient's Rights Ombudsmen and in the Polish Parliament's Act on the Professions of Physicians and Dentists. Performing a treatment procedure without previously collecting valid consent is a crime, resulting in criminal prosecution as severe as up to 2 years in prison. Collecting a patient's consent to be subjected to medical service can be divided into four main phases: checking if consent shall be collected under current circumstances; determining from whom it shall be collected; passing information to the patient or other person entitled to receive it; and actual collection of consent from the person entitled to express it. Each of these can present as a potential ambush for physicians on multiple levels. Consent forms include: contextual, oral and written; and oral consent is quite often questioned by patients, as it is difficult to properly document the details of communication between the physician and patient during a visit. As consent for participation in a medical experiment always requires a written form preceded by passing on relevant information to the patient; it is worth remembering that, according to some interpretations, prescribing drugs off-label to a patent by a physician fits the broad definition of therapeutic experiment. In the context of a patient's consent to receive medical services, the rising need for documenting in medical files not only the patient's final decision, but quite often also many physiciandependent factors as subsequent steps that led the patient to reaching this decision, is noticeably rising. Key words: consent, forensic medicine, family medicine, medical law, legal awareness.

Drobnik J, Trnka J, Susło R. Ambushes related to collecting patients' consent for medical procedures by family doctors. Fam Med Prim Care Rev 2017; 19(3): 298-302, doi: https://doi.org/10.5114/fmpcr.2017.69294.

\section{Patients' consent to receive medical treatment: a historical view}

As recently as 50 years ago, it was not clear that a physician needed to obtain consent to give medical treatment from a patient; even where such consent was expected, its practical application and the understanding were very different from today. It was the 1947 Nuremberg Code, written in response to Nazi war atrocities, that introduced the strict rule that the patient's informed consent - especially in the case of research interventions - was absolutely essential. This was followed in 1964 by the Declaration of Helsinki, which accepted the proxy consent of a relative when the patient lacked decision-making ability [1]. Ideally, the modern patient's consent is voluntary; involves the adequate disclosure of information, including on foreseeable prospects and risks that may arise in the future; is communicated in an appropriate way; is specific to the diagnosis or treatment; and the patient or proxy is mentally capable and legally competent under the circumstances [2]. Patients' right not to be subjected to unwanted medical procedures and to receive only legal, desired medical treatments can be considered two aspects of the basic right to make independent choices guaranteed to all humans in several articles of international law and in the Constitution of Poland, in particular Articles 38-41 and 68 [3]. In recent decades, patients' autonomy (with the patient being understood as a decision-maker acting intentionally, in full understanding, and not being controlled by any internal or external factors) has become a fundamental principle, and even a hallmark, of Western medical professional ethics. The paternalistic approach to patients has thus been widely condemned and seems to be in deep decline [4]. However, there is no guarantee that someday such an attitude will not return; constant and perpetual care is needed, especially considering present-day media discussions of several procedures that are clearly entirely medical in nature (with prenatal diagnostics and abortion as the most vivid examples), which sometimes lead to emotional outbursts and even open violent conflict with casualties [5]. Although in recent decades, such procedures have become easy to perform and safe enough to potentially become widely accessible [6], approaches to them have again begun to be based increasingly often on ideology, rather than on medical science and human rights, including the right to autonomy [7]. We say "again", because the scientific and human-rights-oriented approach to the patient-physician relationship should be considered a great and unique human achievement of the last half century: earlier, approaches were either human-rights-oriented but not scientific (as in ancient Greece); neither rights-oriented nor scientific (as in the Middle Ages in Europe); or, more recently, scientific but not rights-oriented (as in Nazi Germany). The environment in which modern medicine exists depends not only on the objective laws of basic sciences of physics, chemistry, and biology, is also shaped by human law, overseen by politicians, many of whom are fueled by public emotions. These factors lead to the disturbing conclusion that medicine is currently in grave danger of being forcefully turned from the path of development it has followed for the last few decades, which is leading in the direction of an optimal synergy 
of pure scientific foundations that are rooted in a human-rights-oriented approach. Recently, the doors have begun to reopen for medical paternalism to make a return, and also for a general paternalistic approach to medical issues in which power is held by various people, typically lacking medical qualifications, who show a classic paternalistic attitude, feeling that they always know better than the patient; they thus usurp for themselves the right to make decisions for patients based on their own view of what is in the patient's best interest, even when the patients are quite capable of making decisions for themselves [4]. It is thus of crucial importance to observe that the main threat to patients' autonomy, along with their right to consent to medical treatment and indeed even access to treatment, that is faced by medical professionals and modern society as a whole is now general and systemic in nature, rather than relating to one root cause.

\section{Basic practical obstacles associated with patients' consent to receive medical treatment}

The everyday practice of physicians, in the field of primary care and elsewhere, is full of practical difficulties associated with patients' consent to receive medical treatment. A lack of decision-making capacity will make it impossible for a patient to express consent to receive medical treatment. The medical basis for assessing this capacity is, in many countries, traditionally assessed by physicians, especially primary care doctors, though there are increasing tendencies to view capacity more as a technical concept, presumably demanding a fully objective form of testing, including use of psychiatric consultation and scales [8]. Consent must be the result of an informed choice, should uphold patients' dignity, should promote rational decision making, and should allow patients' self-determination [9]. Unfortunately, both everyday experience and academic studies indicate that there is a lack of understanding among patients of the information given to them by their physicians, undermining patients' ability to make decisions [10]. There are thus attempts of various kinds to improve patients' comprehension and retention by including approaches based on modern tools, such as multimedia [11] although the value of audiovisual presentation tools in transmitting the information required for informed consent remains unclear [12]. Many other problems associated with the communication of information result from barriers to communication, differences in culture and customs [13], subjective feelings (or even expectations) of a power asymmetry between doctors and patients, linguistic difficulties, poverty, low education levels [14], and low health literacy in particular [15]. During medical emergencies - when patients may be in pain, anxious, or exhausted - it is both difficult for medical staff to communicate the appropriate information and for the patient to properly absorb it [16]. Although it may sometimes seem that that the longer, more complex, and more in-depth the information shared, the better informed and satisfied the patient will be, in practice, and especially for pre-prepared consent forms, more concise and easier to read forms of communication are appreciated by both patients and medical staff [17], as documents that are lengthy and use complex terminology may be difficult for patients to understand [15]. Consent forms in the USA are typically written at a $15^{\text {th }}$-grade reading level (typically achieved by the third year of college), even though the average reading level in American adults is only about $8^{\text {th }}$ grade and medical authorities typically recommend that the readability level of materials for patients should not exceed $6^{\text {th }}$ grade [18]. Despite the fact that consent forms are essential for the proper transfer of information between medical staff and patients, their readability is often unsatisfactory; such forms also predominantly focus on the risks and benefits of the given medi- cal treatment and fail to properly cover the risks and benefits of alternative treatments and of no treatment [19]. A patient's consent to receive medical treatment also widely functions as evidence of the patient's expressed will, especially in legal and formal proceedings: the widely accepted and commonly used verbal consent is of very doubtful value in this context when expressed without the presence of witnesses and not confirmed in written form; medical staff members are increasingly aware of this problem [20]. Within the limits of local legal ramifications, modern technologies are increasingly often being used to obtain consent to treatment; these include electronic or online forms that offer dynamic content, including hyperlinked information sources and socially sourced comments, which allow patients to augment the process of deliberating on granting consent with the knowledge and experience of others [21]. In more and more cases, obtaining informed consent is evolving towards a self-administered electronic process using mobile technology, including smartphones and mobile apps - although it is still unclear whether such consent-giving processes are capable of fully complying with the three unquestionable tenets of informedness, comprehension, and voluntariness [22].

\section{Legal basis of patients' consent to receive medical treatment in Poland}

A patient's right to express consent or refusal to receive medical treatment is based on Article 15 of the Polish parliamentary Act on Patients' Rights and the Ombudsman for Patients' Rights [23], where not contradicted by any other act of parliament. This Act is consistent with Article 32 of the Act on the Professions of Physician and Dentist [24]. There are several acts that allow for exceptions from this general rule: the exceptions that are most practically relevant to primary care physicians concern medical procedures on drunk drivers required by the police and proceedings in case of mentally disturbed individuals. Article 16 of the Act states that a patient's consent, or refusal, is expressed after the patient has acquired the appropriate information as the patient is entitled. Performing a procedure without having obtained valid consent, where required, is a crime under by Article 192 of the Polish Criminal Code [25], resulting in punishments of up to two years' prison term; however, for the criminal procedure to begin, the injured party needs to submit a complaint to the public prosecutor. Obtaining consent is thus an important aspect of the medical practice of every physician, including primary health care services. The process can be generally divided into four phases: checking whether consent need be obtained under the current circumstances; determining from whom it should be obtained; properly informing the patient or decision maker; and the actual obtaining of the consent from the person entitled to express it. Each of these stages can present a challenge to physicians.

\section{Is the patient's consent to receive medical treatment required under current circumstances?}

In discussing whether consent need be obtained under particular circumstances, it is worth mentioning two situations that are relevant to everyday practice: a police request to take a blood sample from a suspect and a violent psychotic patient confronting a family doctor during a home visit.

Article 47 of the Act on Fostering Sobriety and Preventing Alcoholism [26] states that, where there is suspicion that a crime or offense was perpetrated while the suspect had a blood ethanol concentration of $0.02 \% \mathrm{w} / \mathrm{v}$ or higher in the breath $(0.1 \mathrm{mg} /$ $/ \mathrm{dm}^{3}$ or more), the suspect can be medically tested for blood alcohol concentration; in particular, a blood sample can be taken 
by a medical professional. In practice, this happens most often at a hospital admission room, but in case of difficulty, any medical facility will do, including primary care practices. Article 129 of the Act on Traffic [27] allows the police to request a vehicle's driver (or any person who could reasonably be considered to be the vehicle's driver) to submit to test to determine the blood level of alcohol or other similarly acting substance. Articles $129 \mathrm{i}$ and 129j of the same Act state explicitly that such blood samples can be taken against the suspect's will, though the suspect must be informed in advance. In practice it is important to note that, according to Paragraph 11 of the Minister for Health's Ordinance on Alcohol Concentration in the Body [28], if there is a reasonable suspicion that taking a blood sample could cause a threat to the life or health of the person, a physician must decide whether the procedure will proceed.

Article 3 of the Act on Mental Health Protection [29] defines a mentally disturbed person as a person who is mentally ill, especially psychotic; mentally retarded; or exhibiting other disturbances in mental functions that are medically classified as mental disorders; where such a person requires medical treatment or some other form of support or care to live in a family or social environment. The same Article defines consent as agreement that is expressed freely by a person who is genuinely capable of understanding the information he or she is presented with, including the purpose of hospitalization, state of health, proposed diagnostic and therapeutic procedures, and the foreseeable results executing or not executing these actions. Article 18 of the Act states that if a mentally disturbed person endangers his or her own or another person' life or health, or public safety; or violently destroys or damage objects in their environment; or seriously disrupts or prevents from functioning an institution providing psychiatric medical treatment or social help, it is possible for a physician to decide to use means of direct coercion to be performed under the physician's personal supervision. The forms of direct coercion available to the physician are holding the person still by using physical force or administering a drug against the person's will. Paragraph 12 of the Minister for Health's Ordinance on the Means of Applying, Documenting, and Evaluating Justification of Direct Coercion [30] stipulates that the use of direct coercion needs to be mentioned in individual and common medical documentation.

\section{Who is entitled to express consent to receive medical treatment?}

The second phase in obtaining a patient's consent is determination of the person capable of expressing it. According to Article 17 of the Act on Patients' Rights and the Ombudsman for Patients' Rights [23], any patient older than 16 has the right to express consent or refusal to receive medical treatment. Patient who are 18 or older, and who are not legally incapacitated, mentally ill, or retarded, can independently express consent or refusal. For younger patients, and for those who are fully legally incapacitated or unable to consciously express consent or refusal, consent must be obtained by the physician from the patient's legal guardian; in the case of a diagnostic procedure, consent can also be obtained from a person who is not a legal guardian but who is currently acting as one in caring for the patient. However, for patients older than 16 but not 18 years old yet, or who have sufficient orientation and understanding despite being mentally ill or retarded, the patient has the right to object to medical treatment despite the legal guardian's consent; in such cases, a tutelary court decides. This is consistent with Article 32 of the Act on the Professions of Physician and Dentist [24]. If the legal guardian's consent is needed but the guardian is unavailable, the tutelary court again decides. However, according to Article 33 of the Act, it is permitted to perform medical examinations or other medical service on a patient who needs urgent medical help and, because of his or her health status or age cannot express consent while their legal guardian or person who is currently acting in this role is unavailable; the responsible decision should then consult with some other physician, where available, on the decision to proceed with treatment, and this should be documented in the patient's medical record. Where there is a threat to the patient's health and the legal guardian's consent is needed, but the guardian refuses to give consent, the tutelary court decides; however, if the threat to the patient's health is immediate and the delay resulting from referring the case to the tutelary court would put the patient in danger of losing his or her life or suffering severe bodily damage or a severe disturbance to health, the physician can proceed with the medical procedure needed to prevent such an outcome, after consulting another physician, where possible. The physician is then obliged to put a remark on the procedure and the justification for it into the patient's medical file and immediately pass the relevant information to the patient's legal guardian, person currently acting in this role, or the tutelary court, as applicable. Article 39 of the Act allows a physician to abstain from treatment that is incompatible with the physician's conscience in cases that do not fall under the physician's general duty (listed in Article 30 of the Act) to provide medical assistance in cases where a delay could result in a risk of loss of life; severe body harm, or severe health disturbance; or in any other urgent cases. In such cases, the physician is obliged to place a relevant remark with justification into the patient's medical file and to give the patient directions to find real possibilities of undergoing the refused treatment, provided by another physician or at a different medical facility; the latter duty, together with the duty to proceed with a medical treatment that is incompatible with the physician's conscience in cases of threat to patient's life or health or in urgent cases, was in practice lifted from Polish physicians following a verdict of the Constitutional Tribunal [31]. This exceptional case added another scenario to the list of situations in which a physician is able to refuse treatment [32].

\section{Did the consent to receive medical treatment constitute informed consent?}

The third phase in obtaining a patient's consent is providing the patient (or patient's legal guardian, if applicable) with proper, comprehensible information concerning the patient's health state, diagnosis, offered and available diagnostic and therapeutic methods, the foreseeable results of their use or nonuse, treatment results, and prognosis; each medical professional is obliged to share information about his or her own range of medical services, according to his or her qualifications; however, a patient can also request not to be informed at all. Article 9 of the Act on Patients' Rights and the Ombudsman for Patients' Rights [23] states further that the patient has the right to give personal feedback to the medical professional in response to the received information. A patient older than 16 years should receive enough information to guarantee the proper progress of diagnostic or therapeutic process, consistent with Article 34 of the Act on the Professions of Physician and Dentist [24]. It is important for the physician to document that the information has been properly provided, especially in case of drugs that can have significant side effects, such as negatively influencing the patient's motor skills in traffic and work environments, or posing a special threat for special groups of patients (such as women of reproductive age who could become pregnant while on drugs with potential teratogenic effect) [33]. It is in practice very difficult to properly document the details of communication between the physician and the patient during the visit, as it is not witnessed by any other party, cannot be recorded, and most of the information is passed in verbal form. The physician must thus be ready to anticipate future problems and record in the patient's file remarks that are as detailed as possible, within reason [34]. 


\section{What forms of consent to receive medical treatment are available?}

The actual obtaining of consent or refusal can occur in various forms, including contextual, verbal, and written. According to Article 17 of the Act on Patients' Rights and the Ombudsman for Patients' Rights [23] the contextual form of consent is expressed by the patient's behavior clearly indicating that he or she wishes to receive the given medical treatment, or in the case of contextual refusal, the lack of such a desire. Verbal consent is the most common form, but Article 18 of the Act indicates that it is not sufficient in case of any surgical procedure or any other diagnostic or treatment method that poses an elevated risk to the patient; this is consistent with Article 34 of the Act on the Professions of Physician and Dentist [24]. It is worth remembering that consent obtained by physicians in verbal form can be questioned by patients in case of trouble in the future, so it is reasonable to record consent in a written form in the case of any doubt as to the risk associated with the procedure in the particular patient's case, or even concerning the attitude of the patient who may decide to take a frivolous lawsuit against the medical profession [35].

Medical experiments are a field in which properly obtaining the patient's consent is of special importance. Scientific experiments are typically quite safe in the formal and legal aspect for the participating physician, as they have an established and well-documented methodology that needs to be verified and approved by a bioethical committee. On the other hand, therapeutic experiments in practice are carried out very often at almost every physician's practice as, according to Article 21 of the Act on the Professions of Physician and Dentist [24], such experiments include the introduction by a physician of new or only partially tried diagnostic, therapeutic, or prophylactic method with the aim of producing a direct benefit to a patient's health; such experiment can be carried out if other medical methods have proved to be ineffective or unsatisfactory. According to Article 25 of the Act, informed consent to a medical experiment must be expressed by the patient in written form; if the patient is incapable of writing, however, consent can be expressed verbally in the presence of two witnesses and written into the med- ical file of the patient. According to some legal interpretations, prescribing drugs off-label (that is, for use outside of the approved range of use cases or in groups of patients, including age groups, other than those for who the drug is approved) to a patient constitutes a therapeutic experiment, and the prescribing physician therefore needs to obtain at least the proper written consent to treatment, which would otherwise not be needed in the case of routine prescribing of drugs [36].

Improvements in the process of properly obtaining consent to receive medical treatment can be considered among the many common successes of the clinical and primary care physicians, who implement it, and the public health specialists who strive to adjust the formal environment to facilitate it [37]. As this is a factor that strengthens patients' feeling of autonomy and participation, and at the same time increasing the level of legal safety of medical staff, it positively affects both the patients' quality of life and the quality of medical services [38].

\section{Guidelines for primary care physicians}

From a general point of view, it should be considered every physician's professional duty to foster and conserve positive attitudes towards patients' independence, both within the medical professional and in society in general. It is crucial to stress patients' right to freely choose and access medical services, and especially the importance for patients of being guaranteed that any medical treatment is preceded by a valid granting of consent.

In the everyday practice of primary care physicians, it is important to be aware of the demands associated with the four phases of obtaining a patient's valid consent to receive treatment, and documenting a patient's refusal: checking whether consent is needed under the current circumstances; determining from whom it should be obtained; communicating information to the patient or other person entitled to receive it; and actually obtaining the consent from the person entitled to express it. There is noticeably increasing need to document in medical files not only the patient's final decision, but also the physiciandependent factors that allow validation of the steps that led the patient to making the decision.

\section{References}

1. Rebers S, Aaronson N, Leeuwen F. Exceptions to the rule of informed consent for research with an intervention. BMC Med Ethics 2016; 17: 9, doi: 10.1186/s12910-016-0092-6.

2. Neilson G, Chaimowitz G. Informed consent to treatment in psychiatry. Can J Psychiatry 2015; 60(4): 1-11.

3. Konstytucja Rzeczypospolitej Polskiej z dnia 2 kwietnia 1997 r. (Dz.U. 1997 nr 78, poz. 483 - with subsequent amendments) [cited 27.06.2017]. http://isap.sejm.gov.pl/Download;?id=WDU19970780483\&type=3 (in Polish).

4. Murgic L, Hebert P, Sovic S, et al. Paternalism and autonomy: views of patients and providers in a transitional (post-communist) country. BMC Med Ethics 2015; 16: 65, doi: 10.1186/s12910-015-0059-z.

5. Stack L. A brief history of deadly attacks on abortion providers. New York Times 29.11.2015 [cited 27.06.2017]. Available from URL: https://www.nytimes.com/interactive/2015/11/29/us/30abortion-clinic-violence.html.

6. Olavarrieta C, Ganatra B, Sorhaindo A, et al. Nurse versus physician-provision of early medical abortion in Mexico: a randomized controlled non-inferiority trial. Bull World Health Organ 2015; 93(4): 249-258.

7. Boffey D. Polish government widely condemned over morning-after pill law. The Guardian 26.06.2017 [cited 27.06.2017]. Available from URL: https://www.theguardian.com/world/2017/jun/26/polish-president-signs-off-widely-condemned-morning-after-pill-law.

8. Spike J. Informed consent is the essence of capacity assessment. J Law Med Ethics 2017; 45(1): 95-105.

9. Annas G. Informed consent: charade or choice? J Law Med Ethics 2017; 45(1): 10-11.

10. Tam N, Huy N, Thoa L, et al. Participants' understanding of informed consent in clinical trials over three decades: systematic review and meta-analysis. Bull World Health Organ 2015; 93(3): 186-198.

11. Afolabi M, McGrath N, D'Alessandro U, et al. A multimedia consent tool for research participants in the Gambia: a randomized controlled trial. Bull World Health Organ 2015; 93(5): 320-328.

12. Synnot A, Ryan R, Prictor M, et al. Audio-visual presentation of information for informed consent for participation in clinical trials. Cochrane Database Syst Rev 2014; 5: CD003717, doi: 10.1002/14651858.CD003717.pub2.

13. Bhupathi P, Ravi G. Comprehensive format of informed consent in research and practice: a tool to uphold the ethical and moral standards. Int J Clin Pediatr Dent 2017; 10(1): 73-81. 
14. Chima S. Evaluating the quality of informed consent and contemporary clinical practices by medical doctors in South Africa: an empirical study. BMC Med Ethics 2013; 14(Suppl. 1): S3, doi: 10.1186/1472-6939-14-S1-S3.

15. Budin I, Teare H, Kaye J, et al. Dynamic consent: a potential solution to some of the challenges of modern biomedical research. $B M C$ Med Ethics 2017; 18: 4, doi: 10.1186/s12910-016-0162-9.

16. Lawton J, Snowdon C, Morrow S, et al. Recruiting and consenting into a peripartum trial in an emergency setting: a qualitative study of the experiences and views of women and healthcare professionals. Trials 2016; 17: 195, doi: 10.1186/s13063-016-1323-3.

17. Grady C, Touloumi G, Walker S, et al. A randomized trial comparing concise and standard consent forms in the START trial. PLoS One 2017; 12(4): e0172607, doi: 10.1371/journal.pone.0172607.

18. Eltorai A, Naqvi S, Ghanian S, et al. Readability of invasive procedure consent forms. Clin Trans/ Sci 2015; 8(6): 830-833.

19. Vucemilo L, Borovecki A. Readability and content assessment of informed consent forms for medical procedures in Croatia. PLoS One 2015; 10(9): e0138017, doi: 10.1371/journal.pone.0138017.

20. Lawton J, Hallowell N, Snowdon C, et al. Written versus verbal consent: a qualitative study of stakeholder views of consent procedures used at the time of recruitment into a peripartum trial conducted in an emergency setting. BMCMed Ethics 2017; 18: 36, doi: 10.1186/ s12910-017-0196-7.

21. Balestra M, Shaer O, Okerlund J, et al. Social annotation valence: the impact on online informed consent beliefs and behavior. $J$ Med Internet Res 2016; 18(7): e197, doi: 10.2196/jmir.5662.

22. Doerr M, Maguire T, Bot B, et al. Formative evaluation of participant experience with mobile eConsent in the app-mediated Parkinson mPower Study: a mixed methods study. JMIR mHealth uHealth 2017; 5(2): e14, doi: 10.2196/mhealth.6521.

23. Ustawa z dnia 5 grudnia 1996 r. o zawodach lekarza i lekarza dentysty (Dz.U. $1997 \mathrm{nr}$ 28, poz. 152 - with subsequent amendments) [cited 27.06.2017]. Available from URL: http://isap.sejm.gov.pl/Download?id=WDU19970280152\&type=3 (in Polish).

24. Ustawa z dnia 6 czerwca 1997 r. Kodeks karny (Dz.U. $1997 \mathrm{nr} 88$, poz. 553 - with subsequent amendments) [cited 27.06.2017]. Available from URL: http://isap.sejm.gov.pl/Download?id=WDU19970880553\&type=3 (in Polish).

25. Ustawa z dnia 6 czerwca 1997 r. Kodeks karny (Dz.U. $1997 \mathrm{nr} 88$, poz. 553 - with subsequent amendments) [cited 27.06.2017]. Available from URL: http://isap.sejm.gov.pl/Download?id=WDU19970880553\&type=3 (in Polish).

26. Ustawa z dnia 26 października 1982 r. o wychowaniu w trzeźwości i przeciwdziałaniu alkoholizmowi (Dz.U. 1982 nr 35 , poz. 230 - with subsequent amendments) [cited 27.06.2017]. Available from URL: http://isap.sejm.gov.pl/Download?id=WDU19820350230\&type=3 (in Polish).

27. Ustawa z dnia 20 czerwca 1997 r. Prawo o ruchu drogowym (Dz.U. 1997 nr 98, poz. 602 - with subsequent amendments) [cited 27.06.2017]. Available from URL: http://isap.sejm.gov.pl/Download?id=WDU19970980602\&type=3 (in Polish).

28. Rozporządzenie Ministra Zdrowia z dnia 11 grudnia 2015 r. w sprawie badań na zawartość alkoholu w organizmie (Dz.U. 2015 , poz. 2153) [cited 27.06.2017]. Available from URL: http://isap.sejm.gov.pl/Download?id=WDU20150002153\&type=2 (in Polish).

29. Ustawa z dnia 19 sierpnia 1994 r. o ochronie zdrowia psychicznego (Dz.U. 1994 nr 111, poz. 535 - with subsequent amendments) [cited 27.06.2017]. Available from URL: http://isap.sejm.gov.pl/Download?id=WDU19941110535\&type=3 (in Polish).

30. Rozporządzenie Ministra Zdrowia z dnia 28 czerwca 2012 r. w sprawie sposobu stosowania i dokumentowania zastosowania przymusu bezpośredniego oraz dokonywania oceny zasadności jego zastosowania (Dz.U. 2012, poz. 740) [cited 27.06.2017]. Available from URL: http://isap.sejm.gov.pl/Download?id=WDU20120000740\&type=2 (in Polish).

31. Wyrok Trybunału Konstytucyjnego z dnia 7 października 2015 r. (sygn. akt K 12/14) [cited 27.06.2017]. Available from URL: http:// trybunal.gov.pl/s/k-1214 (in Polish).

32. Susło R, Trnka J, Drobnik J. Odmowa leczenia w przypadku lekarza rodzinnego. Fam Med Prim Care Rev 2008; 10(3): 1086-1090 (in Polish).

33. Drobnik J, Susło R, Trnka J, et al. Znaczenie prawidłowego udzielania pacjentom informacji o lekach w kontekście zagrożeń w ruchu drogowym i miejscu pracy. Fam Med Prim Care Rev 2011; 13(2): 302-304 (in Polish).

34. Susło R, Trnka T, Drobnik J. Prawidłowe dokumentowanie komunikacji lekarza z pacjentem oraz osobami z jego otoczenia i jego rola w wyjaśnianiu podejrzenia popełnienia błędu medycznego. In: Steciwko A, Barański J, eds. Porozumiewanie się lekarza z pacjentem i jego rodzinq: wybrane zagadnienia. Wrocław: Elsevier Urban \& Partner; 2012: 223-233 (in Polish).

35. Susło R, Trnka J, Drobnik J. Roszczenia prawne i skargi pacjentów. In: Steciwko A, Barański J, eds. Relacja lekarz-pacjent: zrozumienie i współpraca. Wrocław: Elsevier Urban \& Partner; 2013: 167-180 (in Polish).

36. Trnka J, Susło R, Drobnik J, et al. Zasady posługiwania się receptami lekarskimi. Fam Med Prim Care Rev 2008; 10(3): 1122-1125 (in Polish).

37. Tyszko Z, Nitsch-Osuch A, Mińko M, et al. Primary health care tasks in implementing the main operations of public health. Fam Med Prim Care Rev 2016; 18(3): 394-397.

38. Kanecki K, Nitsch-Osuch A, Tyszko P. Health-Related Quality of Life or Quality of Medical Service? Current challenges for family doctors. Fam Med Prim Care Rev 2016; 18(3): 382-386.

Tables: 0

Figures: 0

References: 38

Received: 02.07.2017

Revised: 04.07.2017

Accepted: 11.08.2017

Address for correspondence:

Jarosław Drobnik, MD, PhD, Assoc. Prof.

Zakład Gerontologii

Katedra Zdrowia Publicznego UM

ul. Bartla 5

51-618 Wrocław

Polska

Tel.: +48 71 347-90-29

E-mail: jaroslaw.drobnik@umed.wroc.pl 